DOI: $10.17516 / 1997-1370-0352$

УДК $81 ' 25=161.1=134.2$

\title{
Communicative and Textual Competence \\ as a Formative Element in the Subject of Translation in Science and Technology (Russian - Spanish)
}

\author{
Enrique F. Quero Gervilla \\ and Inmaculada Soriano García* \\ Universidad de Granada \\ Granada, Spain
}

Received 15.10.2018, received in revised form 06.11.2018, accepted 20.11.2018

\begin{abstract}
This work is based on our experience as teachers of Translation in Science and Technology at the University of Granada. Based on the model of translation competence created by Dorothy Kelly, in this article we outline a teaching approach which includes different types of activities which further the development of communicative and textual sub-expertise during the training process of this subject.

This proposal is structured around three fundamental objectives: understanding linguistic elements necessary for understanding specialized texts and having the skills to rewrite them; being able to recognize and adequately analyse specialized textual genres in the fields of science in the language combination of Russian-Spanish; recognizing and analysing the necessary terminology to translate specialized textual genres in the fields of Science and Technology in the language combination of Russian-Spanish.
\end{abstract}

Keywords: translation didactics, communicative and textual competence, scientific and technical translation, Russian, Spanish.

Research area: philology.

Citation: Quero Gervilla, Enrique F., Soriano García, Inmaculada (2020). Communicative and textual competence as a formative element in the subject of translation in science and technology (Russian Spanish). J. Sib. Fed. Univ. Humanit. Soc. Sci., 13(3), 352-362. DOI: 10.17516/1997-1370-0352.

(C) Siberian Federal University. All rights reserved

* Corresponding author E-mail address: efquero@ugr.es; isoriano@ugr.es 


\section{Introduction}

The degree in Translation and Interpretation (TeI) at the University of Granada (UGR) is a four-year course and is structured around the study of a first foreign language, which the UGR calls Language $\mathrm{B}$, and a second foreign language called Language C. Four options are offered for Language B: German, Arabic, French and English. Students matriculating in the Faculty of Translation and Interpretation must have a B1 level of competence (according to the Common European Framework of Reference for Languages CEFR), with the exception of Arabic, whose entrance level is A2 or above.

The faculty offers nine options for Language C: German, Arab, Chinese, French, Modern Greek, English, Italian, Portuguese and Russian. No prior knowledge of these languages is necessary (except in the case of French and English where it is normal to expect that students will already have a basic grounding in these languages). In the case in question, Russian, students begin their studies from zero. In the first year they are awarded 18 ECTS credits in Russian, to which another 24 credits are added, distributed over a further two years.

Regarding specialized translation, the curriculum of the current degree offers preliminary contact with specialized translation (scientific and technological as well as legal and economic) to students in the third year, in the subject called Translation B3 (Specialized Translation) which involves the students' first contact with specialized translation in their first foreign language, where they acquire a series of core skills for this area of translation. Thus, creating a foundation for the study of the subject Science and Technology Translation (hereafter TCT) in Language $C$ which is the subject under analysis in this article. We propose a teaching approach for the development of communicative and textual competence in this subject for the combination of Russian-Spanish, taking into consideration the characteristics of the students of Russian in the faculty of Translation and Interpretation at the University of Granada. It should be taken into account that this is a subject involving specialized content aimed at the students' second foreign language, intended for students who began studying Rus- sian in the first year, and who, when they take this TCT subject, have already gained a total of 42 credits in Russian language and 6 credits in Russian culture over six semesters. They will also have had previous experience in specialized translation in their first foreign language, language B, within the subject Translation B3.

Communicative and textual competence is an integral element of translation competence. The development of this competence is the principal objective of the degree in Translation and Interpretation, and its characterization and the analysis of the components of the degree have been studied by various authors (Delisle, 1980; Nord, 1991; Gile, 1996; Hurtado Albir, 1996; Hatim \& Mason, 1997; Kelly, 1999, 2002; PACTE, 2000, Komissarov, 2002: 326), with particular emphasis on the design of the curriculum (Kelly, 2002, 2005; Hurtado Albir, 2007, 2008, 2017; Calvo Encinas, 2011). The model which we have used as our base is the one proposed by Kelly (2002) since we believe, in relation to other models, it is innovative in its addressing of the issue from a professional perspective and is different from previous ones. Kelly defines translating expertise as "the set of skills, abilities, knowledge and even attitudes which are found together in professional translators and which contribute towards translation as an expert activity, that is to say, together they distinguish the professional from the non-professional, the expert from the non-expert" (Kelly, 2002: 9). According to her proposal (Kelly, 1999, 2002, 2005), the components of translating expertise are: communicative and textual competence in at least two languages and cultures, thematic expertise, skilled use of professional tools, psychophysiological competence, interpersonal skills and strategic abilities. Below we will briefly outline what each of these elements of translating expertise consists of and how they are implemented in the subject TCT Russian-Spanish. Further on, we will look in more detail at communicative and textual competence.

Communicative and textual competence in at least two languages and cultures is reflected in this subject in two core areas: on the one hand in the understanding and restating of specialized texts, and on the other hand, 
in the knowledge of textual conventions, and arguments within scientific and technological texts in Spanish and Russian. Firstly, it is indispensable to both understand the original text, and can correctly express the target text (Gile, 1986: 28). At this point special attention needs to be paid to terminology and the role which it plays in the area of specialized communication, as the student must be able to not only identify it in the original text but also be able to employ it in the target text. Secondly this competence is based on the analysis of scientific and technical discourses and in understanding textual conventions in both areas.

Regarding cultural and intercultural competence, the universal nature of scientific and technological discourse should be highlighted, this means that this competence focuses above all on the knowledge of a lexicon with a high proportion of cultural elements. Scientific texts are often perceived to lack cultural elements because of their expository nature and neutrality. However, along the lines presented by Sánchez Trigo and Varela Vila (2015), we are convinced that in these texts it is possible for these elements to be present and to see them reflected, for example, in the non-internationally shared usage of eponyms, medical structures, organizations or practices specific to each culture (Sánchez Trigo and Varela Vila, 2015: 502). It is along these lines that we try to develop competence in the subject TCT, showing students texts in which they themselves can identify and discover cultural references in scientific and technological texts, and the way they can be treated. In this respect, for example, they discover that the law which is known to us as "Lenz's Law" (Ley de Lenz), for the Russians is attributed as much to Joule as to Lenz, and so in Russian it is referred to as "Joule-Lenz's Law" ("La ley de Joule-Lenz") (Закон Джоуля-Ленца). Ultimately, they learn that scientific and medical texts, independent of their neutrality, clarity and objectivity, are written within a specific context and culture.

Thematic competence is based on knowledge of the thematic areas in which a translator works, as well as access to specialized documents which allow translation problems to be solved. Obviously, at this stage in training it is impossible to expect that students will be knowledgeable in all areas of specialization. That said, they are expected to know some basic elements which lead to an understanding and a deeper knowledge of more advanced aspects of this knowledge, as well as being able to manage material sources which will help them to access that information and knowledge which they lack.

Competence in using professional tools is developed during the course, based on the use of documentary, terminology and computer resources amongst others, as well as knowledge of the professional code of ethics and professional associations. This competence develops in tandem with the completion of translation projects which require the use of these resources or where emphasis is placed on the ethical conduct of the translator in various specific cases.

Psychophysiological competence, based on self-concept, confidence, attention span, stress management and task automation, is developed in the subject as in other parts of the degree. As the subject advances, students become aware of what they can achieve. In this way students develop characteristics, such as confidence, as little by little they become aware that they are capable of carrying out tasks which they felt incapable of performing at the beginning of the course.

Interpersonal skills, based on interaction with other professionals (translators, terminologists, documentalists, as well as clients, authors and users, amongst others) are developed in our subject in two main ways: firstly, working groups are formed as much in class as out of it, in a way in which students, while conscious of the advantages of independent learning, have to learn how to work as part of a team (Morón Martín, 2005; Huertas Barros, 2013). In this manner, it is recommended that students organize themselves into groups containing documentalists, translators, terminologists, proof-readers and project leaders and that the roles are rotated over different tasks throughout the duration of the course. To achieve this, the students collaborate following the professional model of Translation teaching proposed in the project AULAINT "Aula virtual de Traduc- 
ción"1 (the virtual translation classroom). The aforementioned setting allows for the recreation of the development of a project as if it were in a translation agency, tackling assignments in an effective and organized manner within the scientific-technological field. Conversely, from the beginning of the subject, stress is placed on the use students make of professionals who can help them to solve specific translation problems arising from the texts which they are working on, particularly professionals from the spheres of health or technology such as doctors, physicists, chemists or biologists. There is no doubt that the interaction between translators and experts is a fairly common working formula in the translation market and thus desirable and always positive in students' training.

Finally, strategic skills, which according to Kelly (2002: 15) are what direct the correct application of all other competencies, develop throughout the course thanks to the use of translations which allow students to develop organizational skills in planning, identifying and resolving problems.

The process of acquiring these competencies is interconnected throughout the different subjects which make up the Degree in Translation and Interpretation. Below we will cover in more detail how communicative and textual competency can be studied in at least two languages and cultures, in this case, Russian and Spanish.

\section{Teaching method}

for developing communicative and textual competency in at least two languages and cultures

We are aware that any teaching method must have an objective. Therefore, before explaining the method itself we will begin by considering what the principal objectives are of the subject related to this communicative and textual competency.

- Knowledge of the linguistic elements necessary in order to be able to understand specialized texts and to have the ability to rewrite them.

Available at: http://aulaint.es/
- Recognition and appropriate analysis of specialized textual genres in the fields of science and technology in the linguistic combination Russian-Spanish. That is to say, awareness of the characteristics of scientific and technological discourse, the characteristics which define this textual typology and the textual conventions in Russian and Spanish.

- Recognition and analysis of the necessary terminology to translate the specialised textual genres in the fields of science and technology in the linguistic combination of Russian-Spanish.

Next, we will develop the particularities of each of the above mentioned objectives as well as some of the teaching proposals as to how to put them into practice.

\subsection{Linguistic elements necessary \\ to be able to understand specialised texts and to have the ability to rewrite them}

Firstly, we believe it is necessary for us to pause and highlight certain particularities which accompany the study of Russian and which subsequently influence the development of translation subjects. These particularities are as follows: as stated above students who study the subject presented in this article have previously attained 42 language credits, 6 Russian cultural credits and one subject of general Russian-Spanish translation (6 credits). During the first three years of translation, students must achieve Level B2 of the CEFR or Vtoroi (Second) from the Russian state system (TRKI). In a relatively short space of time students of Russian must "confront" the translation of specialized texts in an extraordinarily complex language which typologically is very distant from Spanish. This ideal B2 level in Russian conditions the texts which are studied in class to a great extent. For this reason, the very careful selection of texts, which are always authentic, is a central element when addressing the success of this subject. The simple fact that it demands many hours of work and study on the part of the students to be able to read particularly specialized texts fluently must be taken into account. These intrinsic difficulties in the study of Russian lead us to believe that the FTI 
in the UGR should consider that specific languages necessitate greater dedication and that this should equally be reflected in the plan of studies within the undergraduate programme. Namely, we are venturing here to propose that the number of language credits in the Degree in TeI in the FTI should be restructured in relation to the work done and the intrinsic characteristics of Language C. It seems obvious that for students whose mother tongue is Spanish, it will be easier to gain a higher level in Portuguese, Italian or French than in Chinese, Russian or Arab during the first three years of Language $\mathrm{C}$.

Moreover, a further difficulty to be considered is the level of Russian (often fairly unequal) which students have when they enrol on the subject. In relation to this, reference should be made to the wide range of exchange opportunities available to our students in the Russian Federation. Thanks to this, translation students from the UGR can choose to do exchanges lasting 1 or 2 semesters. These places create a lot of interest and are highly in demand. The double degree in Translation and Interpretation (UGR) and Translation and Translation Studies (Moscow State Linguistic University) should also be noted. These exchanges flow in both ways, that is to say, every academic year the FTI accepts Russian students from these universities and obviously they enrol in the subject TCT. This gives rise to a peculiar situation: for the students from Russia the subject automatically becomes a reverse translation subject, while for UGR students it is, as previously seen, a subject of direct translation. As can easily be seen, the level of existing knowledge of Russian is very different, as for some students it is their mother tongue whilst for others it is their second foreign language. This situation affects students as they often perceive it as an 'obstacle' (of both a linguistic and psychological nature) which is difficult to overcome (Soriano García, 2007, 2009, 2009b). Obviously the teaching faculty have to confront this situation and find feasible solutions which ensure the achievement of the identified objectives.

With the aim that every student will overcome this first phase of contact with the subject, which is always difficult, activities are given to develop lexical-grammatical competence and to strengthen their ability to understand specialized texts in Russian and the skill to restate them in Spanish. To further the skill of reading scientific texts, the following activities are carried out:

- Reordering the paragraphs of a disordered text.

- Making a summary of the principal ideas of a text (using a maximum of 300 words).

- Identifying translation problems of a lexical-grammatical nature.

These are combined with cross-language translations intended to improve students' awareness of scientific and technological language in Spanish. For this we provide students with a text written in Spanish with specialized content so that they can rewrite it in a way understandable for "laypeople". This type of exercise allows students to understand the difficulties implicit in understanding a specialized text, and they become aware of the importance that terms acquire as transmitters of knowledge in these texts. The realization of the above mentioned exercises provide an initial contact with the translation process in TCT Russian-Spanish. Consequently, the choice and sequence of the texts is fundamental in the development of students' self-confidence.

\subsection{Textual typology in the fields of Science and Technology in the linguistic combination Russian-Spanish}

The main objective in the analysis of textual typology is that students respect the necessary textual conventions in the target text. We propose a textual typology whose central aim is the differentiation between scientific investigative texts and technological texts based on existing differences between rhetorical devices and linguistic ones present in these types of texts. This brings us to examine the genres between which we differentiate in both subtypes:

$\checkmark$ Scientific texts:

- Scientific texts containing investigation results intended for specialists in each branch of science; reviews and press reports; interviews, specialized investiga- 
tive articles, summaries of specialized texts, chapters of books on specific topics, conference papers etc.

- Texts on popular scientific topics.

- Consultative texts: encyclopaedias, dictionary entries.

- Educational texts: teaching manuals.

$\checkmark$ Technological texts: referring to texts in the areas of Applied Science and Technology, focusing on their function, the following sub-types are distinguishable:

- Technological literature: product labelling, equipment and material specifications, guides and user manuals, patents and cooking recipes.

- Publicity and promotional materials: articles, commercial advertising (pamphlets, medical leaflets), exhibition catalogues, tourist information. It needs to be highlighted that a major part of these texts is often compiled in a digital format: working papers, websites, online shops, certificates, commercial contracts and reports on product quality.

- Software, mobile applications.

Based on this classification, in each case the communicative context needs to be adhered to, as well as the text and the translation assignment, so that the translator knows how to proceed. Students need to be made aware that they have to follow textual conventions in the target text, and consequently they need to know when to discriminate between whether to translate in one way or another. That is to say, at which moment they should adapt the textual conventions of the target text to the target culture or not.

For us, this professional perspective is a vitally important element and as such plays a fundamental role in the organization of the subject. As a result, the topics which are presented to our students correspond to the real necessities of the translation market in the linguistic combination of Russian-Spanish. The following areas have been identified: formal sciences (mathematics, cybernetics, computer science), life sciences (biology, pharmacology, medicine, physics) and different types of engineering (computer engineering, mechanical, electronic, construction, chemical and petro- chemical engineering). In all these fields the most relevant subject matter is as follows:

- Mathematics: scientific modelling;

- Cybernetics: robotics;

- Computer science or computation: information technology, computer industry, electronics, semiconductors, internet, telecommunication devices, e-commerce or IT services;

- Plant biology: agro-industry and industrial plant cultivation;

- Forestry industry and its products: rural and urban furniture and fittings;

- Pharmacology: pharmaceutical manufacturing technology;

- Medicine: diagnostic devices and X-rays;

- Nutrition: food products;

- Software engineering: programming for creating software, video games and artificial intelligence;

- Mechanical engineering: industrial machinery for textile production and hydraulics, technical equipment and appliances (for lifting, transport, excavation, radar), arms (rocketry, firearms, missiles, military airplanes amongst others) and means of transport;

- Electronic engineering: electronic systems and devices;

- Construction engineering: technologies for construction, installation of reinforced concrete constructions, high voltage power lines, power stations, aeronautical infrastructure objects, housing;

- Chemical and petrochemical engineering: industrial products (synthetic fibres, colorants, softeners) and chemical products for plants (pesticides, insecticides and fertilizers);

- Construction materials: plaster, cement, concrete, thermal and acoustic insulation, ceramic and plastic products, waterproofing bitumen products;

- Fine chemicals: medicines, perfumes and cosmetics, beauty products, fertilisers, pesticides and colourants.

Given that the subject is made up of 60 hours, it is impossible to deal with all these areas and topics. For this reason, each year, based on the overall structure, a selection is made taking into consideration the interests and needs of 
the students. The activities which make up our proposal for learning textual typology are:

- analysis exercises of specialized discourses (and the different levels of specialization);

- tasks to recognize different textual typologies in specialized fields;

- textual analysis activities focused on translation;

- analysis and study of different textual forms.

Throughout the first sessions and emanating from the body of texts chosen in Russian, students are encouraged to analyse the characteristics of scientific and technological discourses, and to establish the levels of specialization which are reflected in each. The main objective in textual analysis in translation is to bring students closer to the original text with a well-defined aim: to decide the translation strategies pertinent to each situation. Likewise, this relates to the idea of a translation project and contributes to the automation of the translation process. The activities proposed in this way are based on the textual analysis for translation proposed by Nord (1991). This analysis focuses on the study of extra-textual factors (issuer, intention, receiver, place, time, means, motive, function) and on inter-textual factors (themes, content, assumptions, genre and textual composition, non-verbal elements, lexical elements, syntax, tone, effect) which guide the student, as has been highlighted, towards the translation strategies which they have to apply in each specific situation when translating. They are tasks which are completed before beginning to translate and they allow students to become familiar with the strategies specific to translating specialized texts, prompt discussion and constitute an indispensable tool for orientating students towards when and how they need to adapt the conventions of the target text to the target culture.

We have seen that the implementation of an introductory phase based on the acquisition of certain concepts of specialization, analysis of specialized discourse and textual typology helps students to complete an analysis before translating and subsequently when translating the text.

\subsection{Terminology in the fields of Science and Technology}

From the beginning, students need to be aware that terminology work is not done abstractly, but that it is always a reply to a motive, which in this case is the necessity for a text to be translated. In the same fashion they should be aware that, just as in translation, the quality of the product is directly related to the fulfilment, or not, of the client's requirements of said product. To develop this objective and adequately use terminology, it is necessary to carry out specific tasks associated with skill in the use of translation tools. That is to say, to learn how to use documentary, terminological and computerized sources which offer access to specialized terminology in each translation assignment. This implies carrying out activities which:

- identify and analyse terminology;

- compile glossaries;

- develop conceptual systems.

To introduce students to the identification and analysis of terminology the following activity is offered: students are given an original Russian text and two versions of a Spanish translation. They need to choose the most appropriate version and justify their choice. In one of the translated texts the use of terminology, connectors and textual conventions will be more suitable. As well as giving useful terminology for future translations on the same subject this text also functions as a parallel text.

The main objective of activities connected with the compilation of glossaries is to introduce the student to the practical aspects of handling specialized terminology. Tebé and Cabré (2004: 218) make a distinction between glossaries by the translator and glossaries for the translator (the underlining in the text is the authors'/author's own). The former are glossaries which note diverse solutions offered by a translator during the preparation of a translation and the latter are much more systematic and moreover, contain information which can be useful for taking decisions in the context of a translation. "These glossaries, vocabularies, dictionaries... can contain a lot of useful information for the translator, such as contextual information: contexts, collocations, recom- 
mendations; semantic information: definitions, related concepts, thematic frameworks; grammatical information: grammatical categories, training processes; and pragmatic information: varied formal, professional and geolectal registers, reliable codes, etc." (Tebé \& Cabré, 2004: 218). Along these lines, after being given a text and a specific translation assignment, students are asked to create a bilingual glossary and justify their choice of selected terms chosen for the glossary as well the information it contains (linguistic equivalents, contexts, definitions, comments on usage etc.). Thus the students need to think of themselves as translators who need to use a glossary to decide which information they will record. Obviously they will arrive at the conclusion that the more precise a glossary is (original terms, equal terms, context to be used, definitions, translator's notes, commentaries etc.) the more use it will be for them and their colleagues when they translate further texts during the course.

The creation of conceptual systems in the teaching approach of the TCT is important as it allows knowledge to be organized to establish relationships between concepts and to fine tune unified terminology. All of this without forgetting that it is an indispensable tool for establishing equivalencies between distinct languages. Through conceptual systems we can comprehend the system which shows a set of elements as well as the relationships established between them and which serve to structure all the fields of learning. Furthermore, as Domínguez García and Monterde Rey summarized well in their interview with Heribert Picht (1997: 285): "without a conceptual system the internal relevance of a conceptual device cannot be revealed in a field of learning." The creation of conceptual systems is helped by using the free software programme FreeMind. Students are given a specialized text, and from this, are asked to write a summary and a conceptual system. In this manner, the students begin to develop techniques to analyse a text and locate the concepts which will structure a specific subject. The purpose of this exercise is to produce a conceptual plan where the students have to present all the concepts present in the text as well as the relationships which are established between them. The objective is not to translate the text, but to know in which way the information within it is structured. The activities related to the creation of conceptual systems are extremely useful as they bridge the gap between basic concepts, in general, and in particular, the analysis of a text beforehand, thus preventing students from making mistakes in meaning when they translate texts.

\section{Conclusions}

In this work we have outlined our experience as teachers of Translation in Science and Technology in the combination Russian-Spanish at the University of Granada and we have presented a didactic proposal to develop communicative and textual competence in Russian and Spanish, taking into consideration the conditions of the students and the resources which the undergraduate course in Translation and Interpretation has at its disposal.

The result has been the completion of a teaching proposal specific to the subject of Translation in Science and Technology (Russian-Spanish) organized around a consistent series of activities whose tasks and exercises are based on three fundamental objectives:

1. Knowledge of the linguistic elements necessary in order to be able to understand specialized texts and to have the ability to rewrite them.

2. Recognition and appropriate analysis of specialized textual genres in the fields of science and technology in the linguistic combination Russian-Spanish. That is to say, awareness of the characteristics of scientific and technological discourse, the characteristics which define this textual typology and the textual conventions in Russian and Spanish.

3. Recognition and analysis of the necessary terminology to translate the specialised textual genres in the fields of science and technology in the linguistic combination of Russian-Spanish.

To achieve these objectives and develop communicative and textual competence, pre-translation activities are proposed whose purpose is not to translate the text but to analyse it. For this we propose, amongst other activities: reading comprehension exercises, 
exercises analysing scientific and technological discourses, exercises creating conceptual systems, exercises to access documentation, tasks recognizing different textual typologies in specialist areas, intralinguistic translation exercises, textual analysis exercises orientated towards translation and activities compiling glossaries. None of these activities are done in isolation or out of context but instead they are carried out as translation assignments, helping to determine the strate- gies and techniques necessary for translating texts.

This article does not claim to be an exhaustive list but instead aims to show some examples of how to deal, in a deliberate manner, with introducing students to the practice of specialized translation in the linguistic combination Russian-Spanish, while taking into consideration the development of the different sub-competencies which are part of translation competence.

\section{References}

Alagueva, V.P. (2007). Almaznaia kniga o buriatakh [The Diamond Book about Buryats]. Ulan-Ude: Izd-vo OAO "Respublikanskaia tipografiia”. 96 p.

AULAINT. "Aula virtual de Traducción” [the virtual translation classroom]. Available at: http://aulaint.es

Calvo, E. (2011). "Translation and/or translator skills as organising principles for curriculum development practice". In JoSTrans, 16, 5-25.

Delisle, J. (1980) L'analyse du discours comme méthode de traduction: initiation à la traduction française de textes pragmatiques anglais: théorie et pratique. [Discourse analysis as a method of translation: introduction to the French translation of pragmatic English texts: theory and practice]. Ottawa: Éditions de l'Université d'Ottawa, 282 p.

Domínguez García, C. \& Monterde Rey, A.M. (1997). Terminología y Lenguajes Especializados. Entrevista Al Doctor Heribert Picht [Terminology and Specialized Languages. Interview to Doctor Heribert Picht]. In Revista de Lenguas para Fines Especificos [Journal of Languages for Specific Purposes], 4, 276 291.

Gile, D. (1996). Basic Concepts and Models for Interpreter and Translator Training. Amsterdam/ Philadelphia: John Benjamins Publishing Company, 278 p.

Gile, D. (1986). La traduction médicale doit-elle être réservée aux seuls traducteurs-médecins? Quelques réflexions [Should medical translation be reserved for translators/doctors only? Some thoughts.]. In Meta, 31 (1), 26-30.

Hatim, B. \& Mason, I., (1997). The Translator as Communicator. London: Routledge, 244 p.

Huertas Barros, E. (2013). La competencia interpersonal en la formación de traductores en España. Un estudio empírico-descriptivo del trabajo colaborativo durante la primera etapa de formación en Traducción e Interpretación [Interpersonal competence in the training of translators in Spain. An empirical-descriptive study of collaborative work during the first stage of training in Translation and Interpretation]. PhD. thesis. Universidad de Granada. Available at: https://hera.ugr.es/tesisugr/22074508.pdf

Hurtado Albir, A. (1996). La enseñanza de la traducción directa "general” [Teaching General Translation]

Hurtado Albir, A. (2007). "Competence-based curriculum design for training translators”. In The Interpreter and Translator Trainer (ITT) 1(2), 163-195.

Hurtado Albir, A. (2008). "Compétence en traduction et formation par compétences" [Translation competence and competence-based training]. In TTR: Traduction, Terminologie, Rédaction, 21(1), 17-64.

Hurtado Albir, A. ed. (2017). Researching Translation Competence by PACTE Group. Benjamins Translation Library. Amsterdam: John Benjamins Publishing Company. 401 p.

Kelly, D. (1999). Proyecto docente e investigador [Teaching and research project]. Granada: Universidad de Granada. 
Kelly, D. (2002): Un modelo de competencia traductora: bases para el diseño curricular [A model of translator competence: bases for curriculum design]. In Puentes, 1, 9-20.

Kelly, D. (2005). A Handbook for Translator Trainers. Translation Practices Explained. Manchester: St. Jerome, $186 \mathrm{p}$.

Komissarov, V.N (2002). Sovremennoe perevodovedenie [Modern translation studies]. Moscow: Jets, $242 \mathrm{p}$.

Morón Martín, M.A. (2005). La relevancia de los factores interpersonales en traducción: nuevas fuentes para el diseño curricular [The relevance of interpersonal factors in translation: new sources for curriculum design]. In II AIETI. Actas del II Congreso Internacional de la Asociación Ibérica de Estudios de Traducción e Interpretación. Madrid, 9-11 de febrero de 2005 [Proceedings of the II International Congress of the Iberian Association for the Study of Translation and Interpretation. Madrid, 9-11 February 2005]. Ed. Romana García, M.L. Madrid: AIETI, 129-140. Available at: http://www.aieti.eu/wp-content/uploads/ AIETI_2_MAMM_Relevancia.pdf

Muñoz-Miquel, A. (2015). El desarrollo de la competencia traductora a través de la socialización con el experto en la materia: una experiencia didáctica [The development of translation competence through socialization with the subject matter expert: a didactic experience]. In The Journal of Specialised Translation (23), 333-351. Available at: http://repositori.uji.es/xmlui/bitstream/handle/10234/159635/66557.pdf?sequence $=1 \&$ isAllowed $=\mathrm{y}$

Nord, C. (1991). Text Analysis in Translation. Amsterdam: Rodopi, 274p.

Objetivos de aprendizaje y metodología [The teaching of "general" direct translation. Learning objectives and methodology]". In La enseñanza de la traducción. Col. Estudis sobre la traducción [The teaching of translation. Colection of Estudies on translation]. Ed. Hurtado A. 3. Alicante: Universitat Jaume I, 31-56.

PACTE (2000). Acquiring translation competence: hypotheses and methodological problems of a research Project. In Investigating Translation. Ed. Beeby A., Ensinger D. \& Presas M. Amsterdam: John Benjamins, 99-106.

Sánchez Trigo, E. \& Varela Vila, T. (2015). “Traducción de referencias culturales en textos biomédicos sobre enfermedades neuromusculares (francés-español) [Translation of cultural references in biomedical texts on neuromuscular diseases (French-Spanish)]". In Çédille, revista de estudios franceses [Çédille, journal of French studies], 11, 501-528.

Soriano García, I. (2007). Evaluación de un programa de movilidad en la formación de traductores: expectativas, experiencias y grado de satisfacción de los participantes, profesores y gestores del intercambio MGLU-UGR-ULPGC [Evaluation of a mobility programme in translator training: expectations, experiences and degree of satisfaction of participants, teachers and exchange managers MGLU-UGR-ULPGC]. $\mathrm{PhD}$ thesis: Universidad de Granada.

Soriano García, I. (2009a). Especificidades, necesidades y proyección de futuro del ruso lencua C en los estudios de Traducción e Interpretación [Specificities, needs and future projection of the Russian language $\mathrm{C}$ in the studies of Translation and Interpretation]. In Zinaida Lvóvskaya, In Memoriam. Ed. Bravo Utrera \& García López Bern: Peter Lang, 170-187.

Soriano García, I. (2009b). La situación del ruso lengua C desde la perspectiva del estudiantado de Traducción e Interpretación [The situation of Russian language $\mathrm{C}$ from the perspective of the students of Translation and Interpretation]. In La traducción: balance del pasado y retos del futuro [Translation: Balance of the past and challenges of the future]. Ed. Navarro Domínguez \& Vega Cernuda. Alicante: Editorial Aguaclara, 211-225.

Tebé, C \& Cabré, T. (2004). La constitución de una memoria terminológica: elaboración de terminologías bilingües en programas de memoria de traducción [Creation of a terminology memory: development of glossaries of bilingual ternims in translation memory programs]. In Linguistica Antverpiensia 3, 217-227. 


\title{
Коммуникативная и текстовая компетентность \\ как формирующий элемент научно-технического перевода (русско-испанская языковая пара)
}

\author{
Э. Ф. Керо Хервилья, И. Сориано Гарсия \\ Университет Гранады \\ Испания, Гранада
}

\begin{abstract}
Аннотация. Работа основана на опыте преподавания предмета «Научнотехнический перевод с русского на испанский» в университете Гранады. Основываясь на модели переводческой компетенции Д. Келли, мы предлагаем оригинальный метод, позволяющий студентам развивать в процессе обучения навыки устного и письменного перевода с использованием разных видов речевой деятельности для достижения следующих целей: овладение элементами языковой системы, необходимыми для интерпретации специализированных текстов, и способами их передачи на другой язык; знакомство с жанрами научно-технической литературы и документации на русском и испанском языках и анализ текстов, относящихся к данной области; овладение технической терминологией и лексикой для перевода текстов на испанский или русский язык.
\end{abstract}

Ключевые слова: дидактика перевода, коммуникативная и текстовая компетентность, научно-технический перевод, русский язык, испанский язык.

Научная специальность: 10.00.00 - филологические науки. 